\title{
Incisor agenesis: paradigm shift A study of an orthodontic population Clinical cases
}

\author{
H. Poulet, C. Poulet, C. Poulet
}

\begin{abstract}
Our study among an orthodontic population of 1,095 patients indicates that $9 \%$ of the subjects have at least one agenesis $13 \%$ for maxillary lateral or mandibular central/lateral incisors).

Regarding possible treatments, we evaluated the different solutions from the less invasive to the most invasive: simple space closure, space closure with laminated veneers, space opening with a cantilevered bonded bridge, space opening with implant.

Recent advances in biomimetic dentistry suggest that now is the time for a paradigm shift.
\end{abstract}

\section{KEY WORDS}

Agenesis, incisor, laminated veneer, cantilevered bonded bridge, implant, biomimetism

\section{INTRODUCTION}

A study carried out in our office shows that 3 patients in 100 present with at least one congenitally missing incisor land for the vast majority an agenesis of the maxillary lateral incisor).

Proper management of patients with a congenitally missing incisor amounts to choosing - in consultation with them? the best possible functional and aesthetic compromise, all with an eye to the longterm result. These choices involve opening or closing the space of the missing tooth. There are numerous criteria to take into account to help in making the decision (Arvystas ${ }^{2}$ ).

Space closure for the missing maxillary incisor leads invariably to the need of a remodeling of the canine into a lateral 


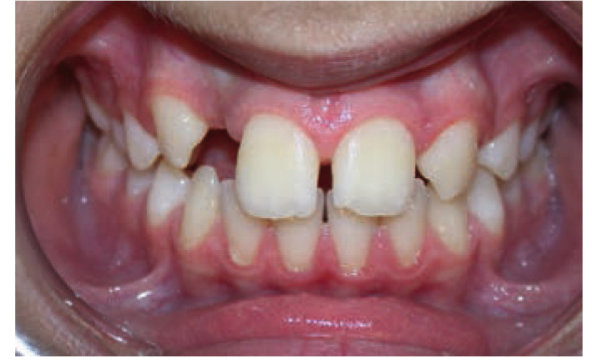

Figure 1

incisor and the first premolar into a canine $^{24,30,31,43,44 .}$

\section{ETIOLOGY OF AGENESIS}

Most part of dental agenesis has a genetic origin, caused either by chromosomal defects ${ }^{17}$ or by mutations occurring during replication of the chromosomal DNA ${ }^{7}$. A great number

\section{METHOD}

In this project, we have chosen to study, among our orthodontic population, 1680 consecutive files to determine the prevalence of subjects with at least one congenitally missing tooth (Fig. 1).

We voluntarily excluded missing wisdom teeth as well as patients with a history of extractions of permanent teeth.

The remaining patients must have at least a panoramic radiograph in

\section{RESULTS}

Ultimately, our sample consists in 101 patients with at least one congenitally missing tooth or $9.22 \%$ of the orthodontic population studied (for a
Based on recent findings in the field of dentistry, opening space poses a dilemma when it comes to recommending a solution. The current paradigm leads the practitioner towards choosing an implant ${ }^{15}$. But is this the best solution over the long term? Should we perhaps consider a reliable, long-term alternative? Biomimetic ${ }^{22}$ dentistry seems to provide a different answer to this problem that must be examined with the greatest care.

of non-Hox genes are implicated in this these phenomena (MSX $1^{41}$, $\mathrm{PAX9}^{8}$, WNT10A ${ }^{32}$, etc.) without a formal demonstrated individual role.

their orthodontic file. After exclusion, our population consisted in 1,095 patients fulfilling these criteria.

The average age of this population is 152 months, or 12 years and 8 months (SD 3 years and 4 months). The youngest patient is 7 years of age and the oldest 39 years and 8 months.

The division by sex is balanced (831 boys for 849 girls).

total of 176 congenitally missing teeth).

The ratio by sex is 3 girls for 2 boys (61 girls, 40 boys), results 
confirmed for a Caucasian population by Bergström ${ }^{5}$, Brooks ${ }^{11}$ and Suarez and Spence ${ }^{23}$.

The average age for the sample is 152 months or 12 years 8 months (SD 36 months or 3 years).

Here is the distribution of 176 congenitally missing teeth according to their location:

\begin{tabular}{|l|c|c|}
\hline \multicolumn{1}{|c|}{ Maxilla } & Number & Percentage \\
\hline Central incisor & 0 & 0 \\
\hline Lateral incisor & 53 & $30.29 \%$ \\
\hline Canine & 1 & $0.57 \%$ \\
\hline First premolar & 2 & $1.14 \%$ \\
\hline Second premolar & 28 & $16 \%$ \\
\hline First molar & 0 & 0 \\
\hline Second molar & 0 & 0 \\
\hline
\end{tabular}

\section{DISCUSSION}

The different specialties of dentistry (orthodontics, prosthodontics, aesthetic dentistry and restorative dentistry) must combine their skills to provide patients with congenitally missing teeth the best results possible in terms of aesthetics and function that will last as long as possible. The practitioner must evaluate and propose treatment with the best ratio between the cost/benefit/risk.

Armbruster ${ }^{1}$ warns us: the assessment of the final aesthetic result, whatever option considered, remains very subjective and varies from one person to the other (health professional or patient). We must be able

\begin{tabular}{|l|c|c|}
\hline \multicolumn{1}{|c|}{ Mandible } & Number & Percentage \\
\hline Central or lateral incisor & 13 & $6.86 \%$ \\
\hline Canine & 0 & 0 \\
\hline First premolar & 2 & $1.14 \%$ \\
\hline Second premolar & 72 & $41.14 \%$ \\
\hline First molar & 0 & 0 \\
\hline Second molar & 5 & $2.85 \%$ \\
\hline
\end{tabular}

These results are practically identical to those obtained by the author ${ }^{24}$ in a previous study.

In decreasing order, the most frequent congenitally missing teeth are the mandibular second premolars $(41 \%)$, the maxillary lateral incisors $(30 \%)$, the maxillary second premolars $(16 \%)$, the mandibular incisors (around $7 \%$ )... .

For this article, we will only focus on the missing incisors.

to identify the aesthetic expectations of our patients to be able to satisfy them.

We will follow the recommendations of Tirlet and Attal ${ }^{37}$ who discuss a therapeutic gradient for the solutions we provide to our patients (Fig. 2).

For the less invasive treatment (with the weakest cost/benefit/risk ratio) to the most binding treatment choice, here are the different solutions that are offered to our patients:

- Simple space closure of the congenitally missing tooth with simple reshaping of the canine 


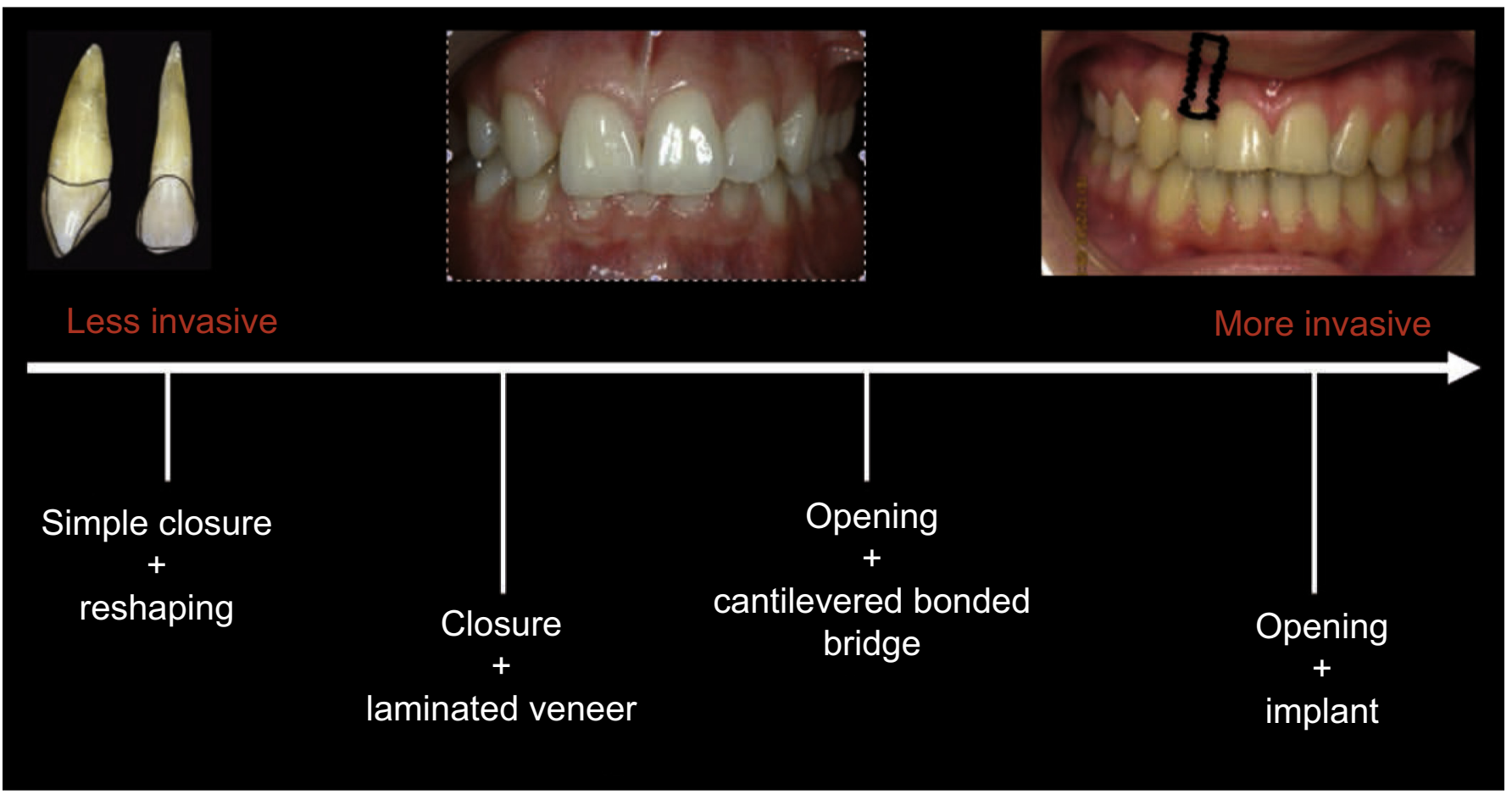

Figure 2

Modified therapeutic gradient (from Tirlet and Attal ${ }^{32}$ ).

into a lateral incisor (cosmetic reshaping) and of the first premolar into a canine (composite resin build up possible);

- Space closure for the congenitally missing tooth with morphological modification by the use of laminated veneers;

- Opening the space with replacement of the missing incisor with a cantilevered bonded bridge;

- Opening of the space with replacement of the missing incisor with an implant.

Each one of these options must be considered and discussed with our patient to provide him the highest satisfaction.

Numerous factors influence the decision-making ${ }^{16,24}$ :
- skeletal (brachy- or dolichofacial):

- vertical excess being favorable for space closure;

- dental:

- occlusal: dental Class III militates for space opening for the congenitally missing tooth even if Ludwig, Zachrisson and Rosa ${ }^{21}$, Rosa and Zachrisson ${ }^{30,31}$, Zachrisson ${ }^{43}$ and Zachrisson, Rosa and Tores$\mathrm{kog}^{44}$ propose mesialization of the lateral sectors with closure of the anterior space and opening of a posterior space. Obtaining a "classic" Class I between the canines does not have to be a dogma. Nordquist and Mc Neill ${ }^{25}$ and Robertson and Mohlin $^{29}$ have shown that after 
space closure for the congenitally missing tooth, leading to a Class I between the maxillary first premolar and the mandibulary canine, the occlusion was perfectly functional over the long-term (no articular dysfunction) and stable from a periodontal point of view;

- overlaps or diastemas;

- more specifically, the color, shape, and size of the canine;

- smile line: a gingival (gummy) smile advocates for space closure ${ }^{43}$.

We will consider the different possibilities for treatment, by evaluating the advantages and the disadvantages of each solution by beginning with the simplest.

\section{Closure of the space for the congenitally missing tooth}

\section{- Simple (without using a prosthesis)}

It requires a coronoplasty of the canine into a lateral incisor and of the premolar into a canine. This solution evidently remains the simplest to use as far as it is achievable. It presents, for the patient, the cheapest proposition because it only involves orthodontics and cosmetic remodeling of certain teeth. The most favorable cases are those where the canine is small with a low saturated color, close to the central incisor's one.

The orthodontic treatment should extrude the canine so that it has a collar line as natural as possible. Tuverson ${ }^{39}$ and Thordarson and Zachrisson $^{35}$ show how grinding the canine is harmless over the longterm, validating the choice of this solution.
Grinding can be completed by the addition of composite resin (a very slightly invasive procedure) in order to perfect the final aesthetic appreciation, composites have the advantage of being able to be renewed easily in case of deterioration of their appearance.

Case number 1 Maureen, 7 years old, with congenitally missing lateral incisors, a Class II right side malocclusion, a right lateral crossbite and a dolichofacial typology. The orthodontic treatment will be divided into two phases.

The first corrective phase for the transverse problem was accomplished with a quad helix over a 6-month period.

The fixed appliances were bonded at 12 years of age after the extraction of the two mandibulary first premolars in order to correct the significant lower anterior crowding. The cosmetic reshaping of the canines was done progressively during treatment to minimize any pulp reactions (Fig. 3 to 12).

\section{- With laminated veneers}

The development of aesthetic dentistry, with the concept of biomimetic dentistry introduced by Magne and Belser $^{22}$ and relayed to France by authors such as Tirlet ${ }^{36}$, Attal $^{3}$ and Etienne $^{15}$, makes it possible, even indispensible, to integrate laminated veneers into our treatment plans. Manhart $^{23}$ and Etiennne ${ }^{15}$ describe a detailed approach of the fabrication of these prosthesis and show all the aesthetic benefits they offer. Tirlet and Bazos" evoke "the ceramic/composite resin/enamel-dentin 

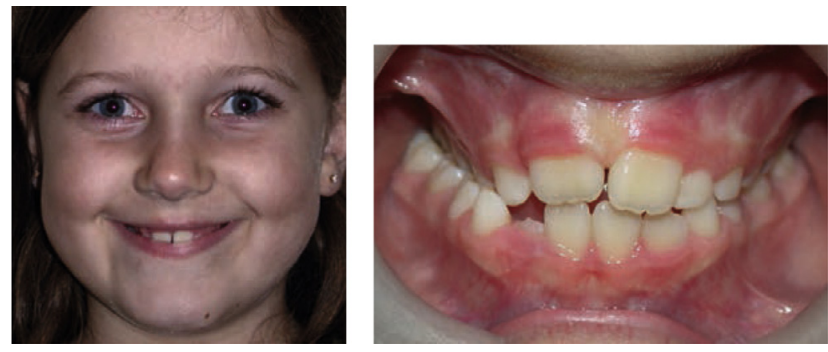

Figures 3 and 4

First phase of treatment with a quad helix (7 years of age).
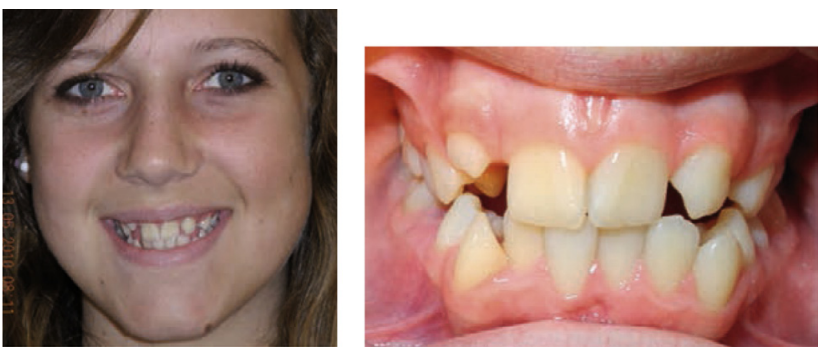

Figures 5 and 6

Beginning of fixed appliances treatment (12 years of age).
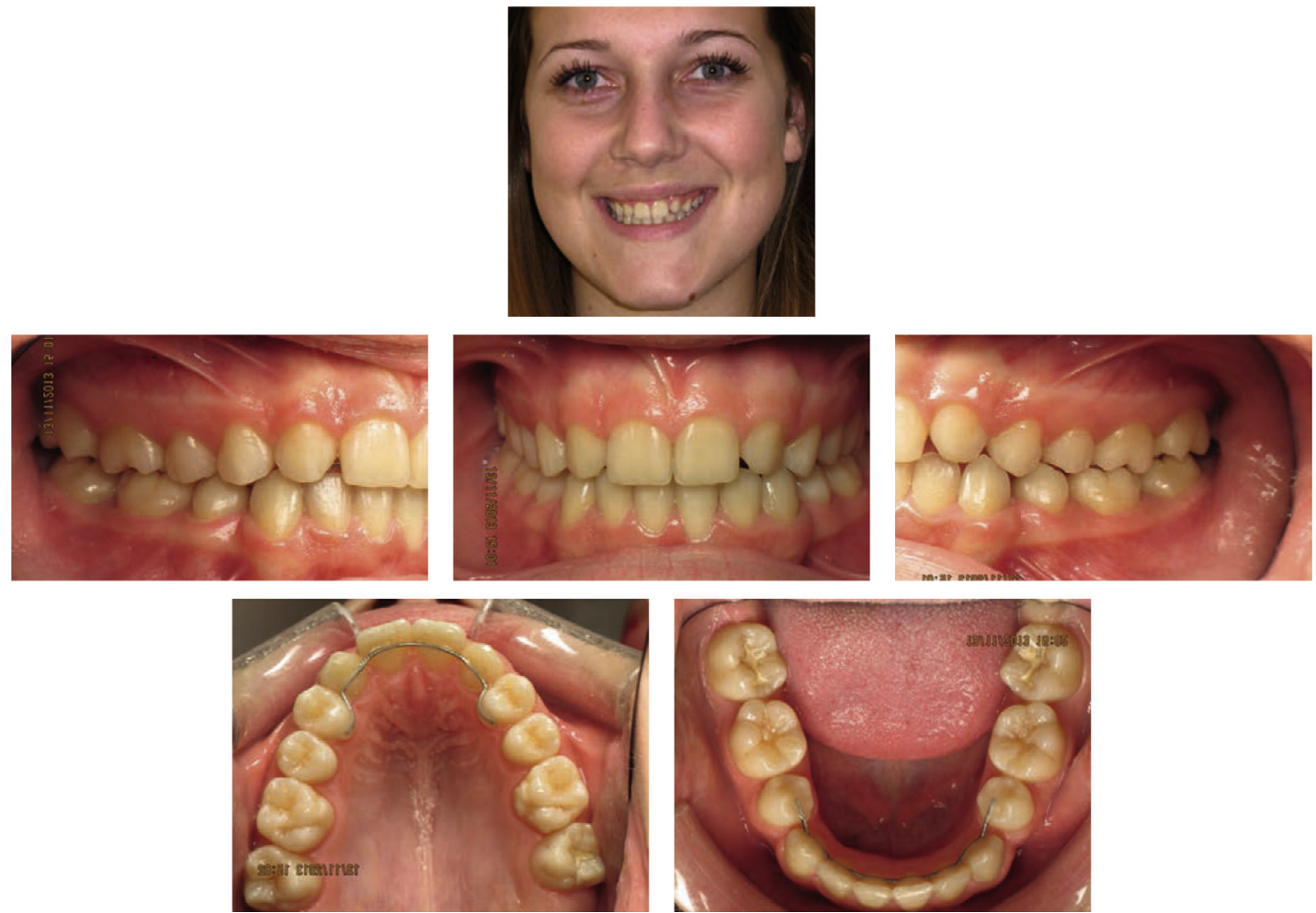

Figures 7 to 12

End of orthodontic treatment after cosmetic reshaping of the canines and maxillary first premolars. 
adhesive complex consisting of components of the natural tissues bio-emulation unit" with the aesthetic results that imitate Nature.

Laminated veneers streamline treatment plans that include space closure and modifications of the shape and color of certain teeth.

Rosa and Zachrisson ${ }^{30,31}$, Ludwig, Zachrisson and Rosa ${ }^{21}$, Zachrisson ${ }^{43}$, Zachrisson, Rosa and Toreskog ${ }^{4}$ show the advantages of this solution over the long-term with the natural evolution of the dentition throughout the ageing process. The final aesthetic result is obtained rapidly as compared to different treatment using implants (they are contraindicated in growing adolescents) in which a removable prosthesis is used for many years.

One of the potential problems of this solution is the tendency for the anterior diastemas to reopen; this unsightly effect can be avoided by using a fixed retention ${ }^{43}$.

Case number 2 (courtesy of Dr. Zachrisson) is of a young girl, 14 years old, presenting with a unilateral congenitally missing lateral incisor with a right side dental Class II and an incisor overbite. After the

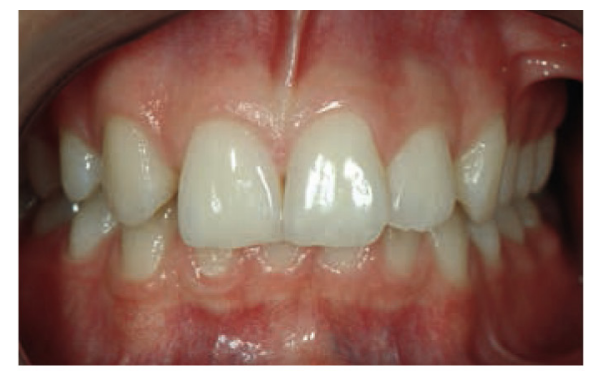

a extraction of the left first premolar, the final result was obtained trough the use of laminated veneers on the right maxillary canine and first premolar (Fig. 13a and b).

\section{Opening of the space for the congenitally missing tooth}

The most favorable cases are represented by:

- Class I occlusion to dental Class III with small sized teeth;

- the presence of maxillary diastemas and/or mandibular overlapping;

- skeletal brachyfacial typology;

- a smile that reveals little of the maxillary incisors.

\section{- With a cantilevered bonded bridge}

Given the enormous progress made over the last few years in the areas of adhesive dentistry and the quality of the ceramics (durability, appearance), we had to consider using aesthetic, biomimetic, bio-emulative dentistry (Magne and Belser ${ }^{22}$, Manhart ${ }^{23}$, Tirlet and Bazos $^{38}$ ) in the development of our treatment plans.

In cases in which opening space is the most appropriate issue, this solu-

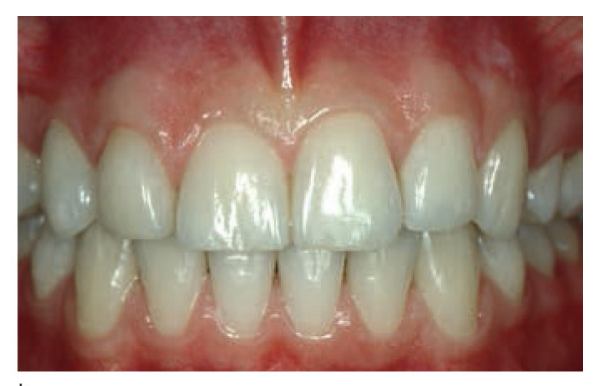

b

Figure 13

a) Frontal intraoral view before treatment; b) After orthodontic treatment (Dr. Zachrisson) and placement of laminated veneers on 13 and 14 (Dr. Toreskog). 
tion remains much less invasive than using an implant.

A number of studies have demonstrated the stability and the high success rate of cantilevered bonded bridges (with a single abutment) (Attal $^{13}$, Attal, Coudray and Tirlet ${ }^{4}$, Botelho, Chan, You and Tse ${ }^{9}$, Botelho, Leung and Chan $^{10}$, Lam, Botelho and McGrath $^{18}$, Feilzer and Klevarlaan ${ }^{40}$ ).

Wong and Botelho ${ }^{42}$ show the superiority of the cantilever over the classic bridge (3 units) when subjected to an occlusal load. This argument strongly supports the use of a cantilevered bridge in the incisorcanine area where the occlusal stress is significant.

The quality of the restoration depends on the technical ability of the lab technician (form, color, appearance) to reproduce and to imitate Nature ${ }^{36}$.

Lam, Botelho and McGrath ${ }^{18}$ and Lam, McGrath and Botelho ${ }^{19}$ note that patients do not see any difference between implants and cantilevered bridges in the results obtained. In contrast, they point out that after 5 years, the cantilevered bridges present fewer biological complications than the implants.

Finally, the placement of a cantilevered bonded bridge can be done at the end of orthodontic treatment ${ }^{36}$ (even if growth has not ended) and thus avoids the critical phase for the patient of wearing a removable prosthesis.

The behavior of the dental support and the tissues surrounding the cantilevered bridge over ageing is identical to the adjacent teeth.

Case number 3 (courtesy of Dr. Tirlet) shows the perfect aesthetic integration of the cantilevered bonded bridge. This young girl, 14 years of age, presents two congenitally missing maxillary lateral incisors; at the end of the orthodontic treatment, two cantilevered bonded bridges are placed with two chips on the two maxillary canines (Fig. 14 to 19).

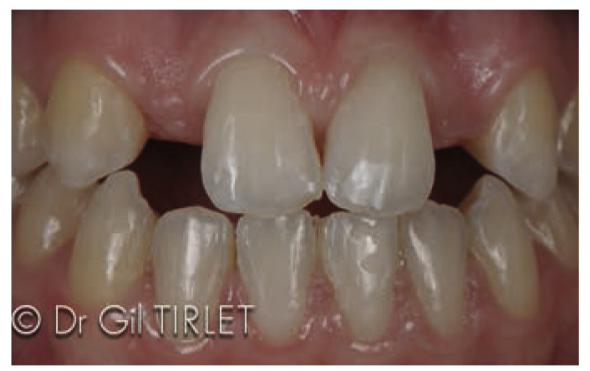

Figure 14

After orthodontic treatment (Dr. Beaugrand).

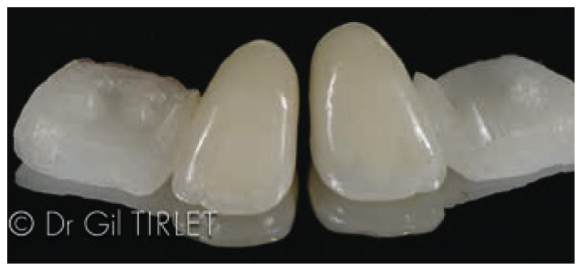

Figure 15

The two cantilevered bridges in Emax ceramic (Esthetic Oral laboratory, Helene et Didier Crescenzo).

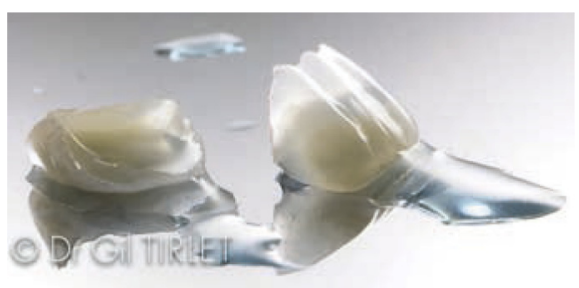

Figure 16

Chips on 13 and 23 in Emax ceramic (Esthetic Oral laboratory, Helene et Didier Crescenzo). 


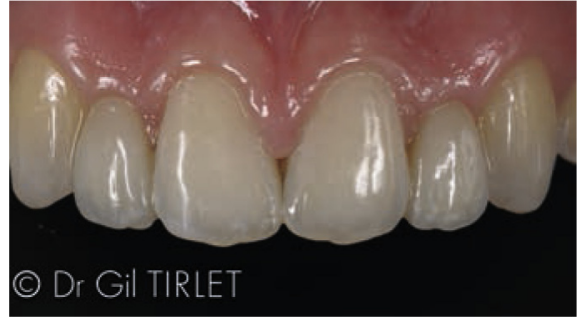

Figure 17

Frontal intraoral view of the cantilevered bridges in place lafter recontouring lovalization) of the gingival crest by soft laser).

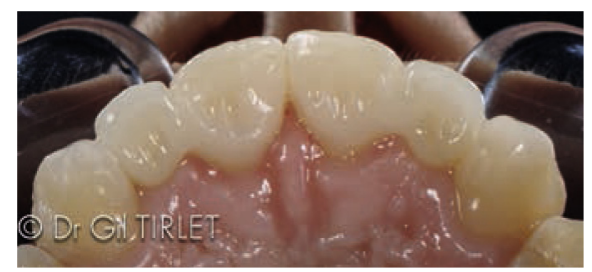

Figure 18

Occlusal intraoral view of the cantilevered bridges in place.

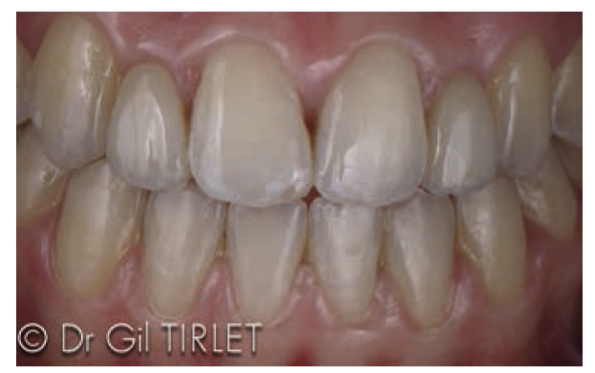

Figure 19

Frontal intraoral view after 3 years follow up.

\section{- With implant}

The elevated rate of long term success mitigates in favor of the use of an implant in the lateral incisor location; the principal advantage remains in the total absence of prosthetic devices on the teeth that border the space of the agenesis.

Mesial eruption of the canine is a bonus; secondary distalization of this tooth leads to a new formation of bone whose dimensional stability (height, thickness), during that time, allows for the placement of the implant without a bone graft ${ }^{16}$.

The practitioner should leave at least $1.5 \mathrm{~mm}$ on each side of the future implant in order to preserve the interdental papillae.

This present solution however has a number of pitfalls (Rosa and Zachrisson ${ }^{30,}{ }^{31}$ ):

- the waiting time between the end of orthodontic treatment during the adolescent period and the ideal moment to place the implant (end of growth), that is 17-18 years of age for a girl and 19-20 years of age for a boy. A temporary removable prosthesis will be necessary but it is sometimes poorly accepted by the adolescent (psychological handicap);

- the risk of root movement (incisor, canine $)^{27}$ despite the placement of a bonded retainer on the central incisors and between the canine and first premolar can contraindicate the placement of the implant (Fig. 20 to 22);

- The risk of a progressive bone wasting (horizontal or vertical bone loss);

- The absence of certainty as to the ageing of the implant from a periodontal point (possible appearance of an unaesthetic greyish bordered gingival dehiscence ${ }^{13}$, bluish coloration of the gingivae ${ }^{14}$ ) and mostly occlusal with an similar behavior to an ankylosed tooth (appearance of a difference in the vertical position - "reintrusion") 6, 34 . The vertical movement of the 


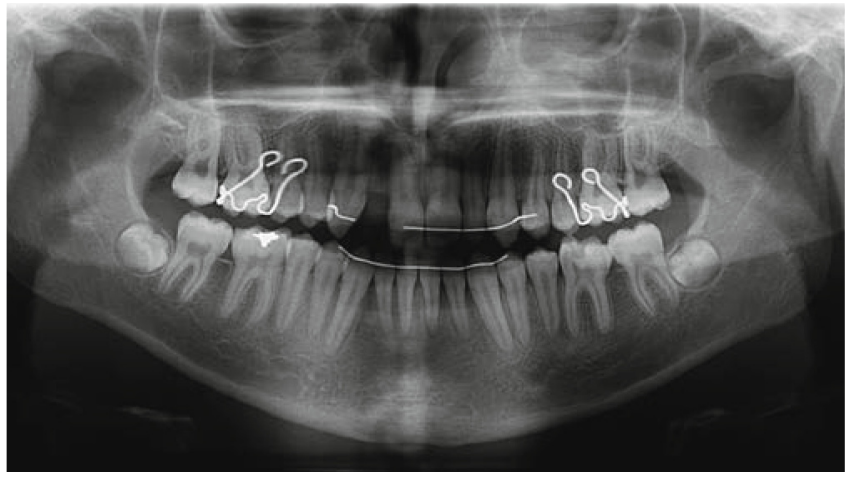

Figure 20

Panoramic radiograph at the end of orthodontic treatment. 11-24 and 13-14 retaining wires are bonded accompanied by a palatal plate to replace 12 .

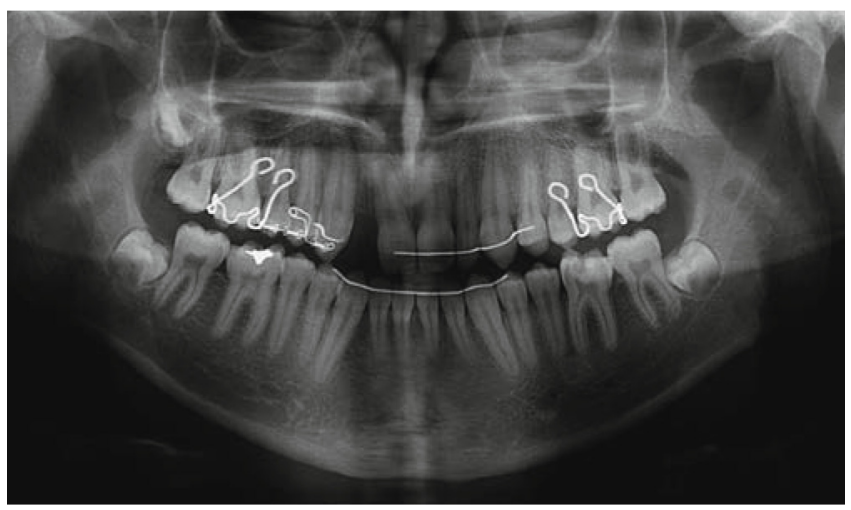

Figure 21

Panoramic radiograph 3 years post retention showing apical displacements (distal 11 and mesial 13) making it impossible to place an implant.

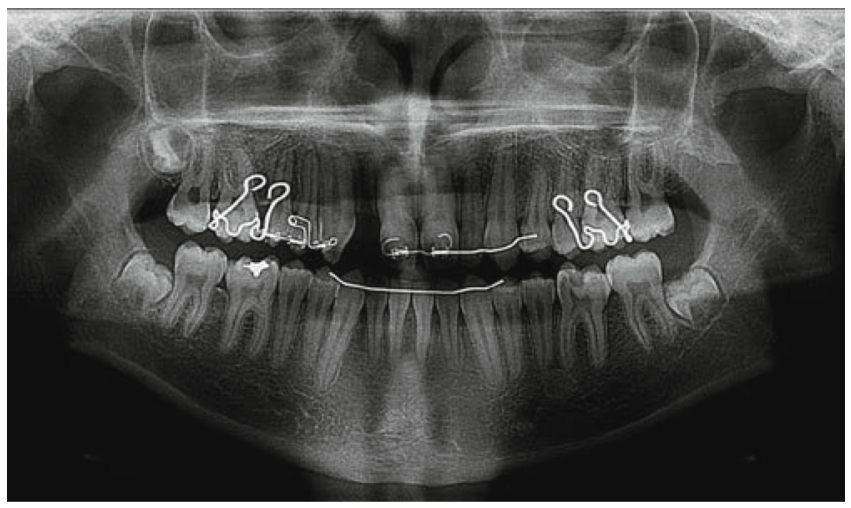

Figure 22

Panoramic radiograph showing orthodontically uprighting of the 13 and 11 (6 months treatment length). incisors throughout ageing results to a progressive protrusion of the implant (Oesterle and Cronin ${ }^{26}$ Thilander, Odman and Lekholm ${ }^{34}$ ). These authors advise that the patient be warned of these possible aesthetic alterations with ageing, due to changes in the peri-implant environment, requiring modifications of the implant crown (Fig. 23 and 24).

The future certainly appears to be genetic engineering and the possibility to "create" a new tooth from stem cells, (Cai et al. ${ }^{28}$ ).

Case number 4 illustrates a satisfactory result, in any case over the short-term, of an implant solution. Meyrine, 14 years of age, presents with congenitally missing maxillary right lateral incisor with a skeletal Class III tendency brachyfacial pattern and a Class I dental pattern with several diastemas. (Fig. 25 to 28).

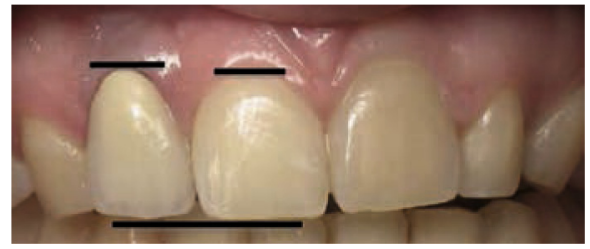

Figure 23

Implant 12 the day of placement in 2008 in a young girl, 18 years of age.

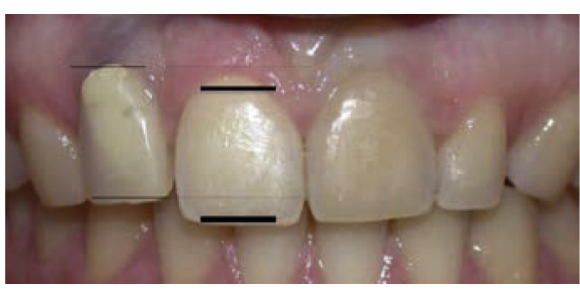

Figure 24

Five years later, "intrusion" of the implant. 


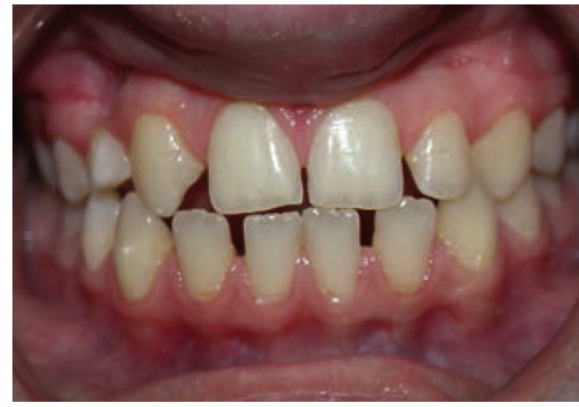

Figure 25

Frontal intraoral view before orthodontic treatment.

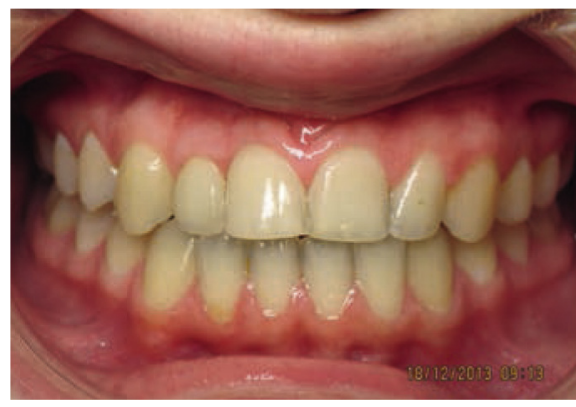

Figure 27

Frontal intraoral view 3 years post retention (implant in place for 2 years, Dr. Bailly).

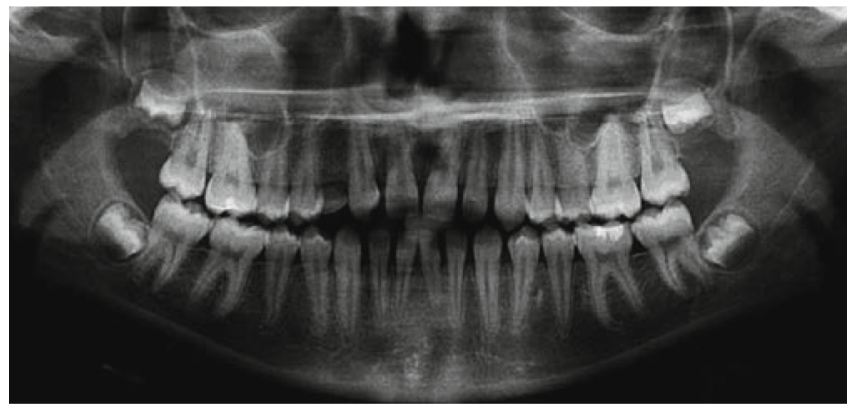

Figure 26

Panoramic radiograph before treatment.

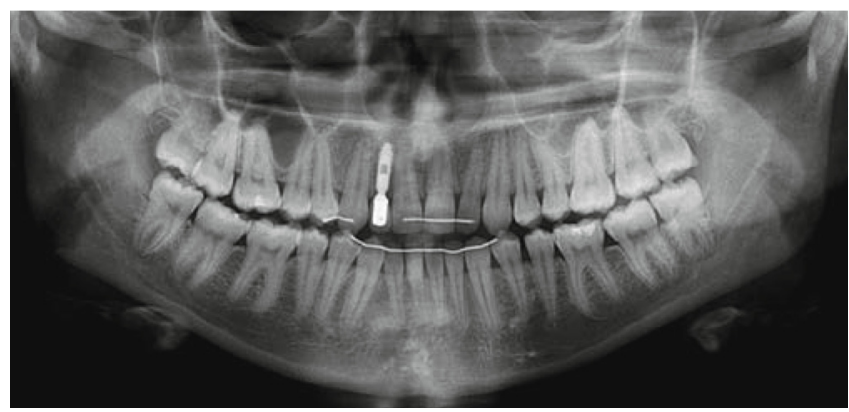

Figure 28

Panoramic radiograph 3 years post-retention.

\section{CONCLUSION}

The relatively significant number of patients with at least one congenitally missing incisor (3 patients in 100 in our study) makes each orthodontist ask himself this question: should I open or close the space?

Lehman $^{20}$ guides through the process towards making a therapeutic decision.

Tirlet and $\mathrm{Attal}^{37}$ recommend that we always begin, when it is possible, with the simplest solution, the most economical for the tissues, with the best cost/benefit/risk ratio.
Space closure for the congenitally missing tooth when it is possible, seems to be the most favorable treatment (simple closure with cosmetic recontouring or with application of laminated veneers).

Space opening for the congenitally missing tooth with the placement of an implant can not be considered as a panacea in view of the many questionable events that can occur with ageing that are not controllable in the tissues surrounding the implant. 
Biomimetic dentistry, through the cantilevered bonded bridge, brings a long-lasting solution to the replacement of the missing tooth and must absolutely be a part of our therapeutic arsenal.

Finally, works in progress (Cai et al. ${ }^{12}$, Oshima et $a l^{28}$ ) and yet to come in genetic engineering with stem cells give us great hopes for the creation of "natural" teeth substitute.

Conflicts of interest: The author declares no conflict of interest.

\section{BIBLIOGRAPHY}

1. Armbruster PC, Gardiner DM, Whitley JB Jr, Flerra J. The congenitally missing maxillary lateral incisor. Part 1: esthetic judgment of treatment options. World $\mathrm{J}$ Orthod 2005;6(4):369-375.

2. Arvystas M. Orthodontic management of agenesis and other complexities: An interdisciplinary approach to functional esthetics. London and New York: Thieme Publishing, New York Taylor \& Francis, 2003; 227 p.

3. Attal JP. Bridge collé cantilever. Blog JP Attal 2012;message $n^{\circ} 13$.

4. Attal JP, Coudray L, Tirlet G. Bridge collé cantilever en céramique de haute ténacité assemblé à l'aide d'une colle réactive. Le Fil Dentaire 2008;37:38-42.

5. Bergström K. An orthopantomographic study of tooth agenesis, supernumeraries and other anomalies in school children between ages of 8-9 years. Swed Dent J 1977;1:145-157.

6. Bernard JP, Schatz JP, Christou P, Belser U, Kiliaridis S. Long-term vertical changes of the anterior maxillary teeth adjacent to single implants in young and mature adults. A retrospective study. J Clin Periodontol 2004;31(11):1024-1028.

7. Bisseret $F$. Étiologie des agénésies dentaire d'origine génétique. Thése pour le diplôme d'État en chirurgie dentaire. Nantes, 2009.

8. Boeira BR Jr, Echeverrigaray S. Novel missense mutation in PAX9 gene associated with familial tooth agenesis. J Oral Pathol Med 2013;42(1):99-105.

9. Botelho MG, Chan AW, You EY, Tse ET. Longevity of two-unit cantilevered resin-bonded fixed partial dentures. Am J Dent 2002;15(5):295-299.

10. Botelho MG, Leung $\mathrm{KC}, \mathrm{Ng} \mathrm{H}$, Chan $\mathrm{K}$. A retrospective clinical evaluation of two-unit cantilevered resinbonded fixed partial dentures. J Am Dent Assoc 2006;137(6): 783-788.

11. Brooks AH. Dental anomalies of number, form and size: their prevalence in British school children. J Int Assoc Dent Child 1974;5:37-53.

12. Cai J, et al. Generation of tooth-like structures from integration-free human urine induced pluripotent stem cells. Cell Regeneration J 2013;2:6-13.

13. Cardaropoli G, Lekholm U, Wennström JL. Tissue alterations at implant-supported single-tooth replacements: a 1-year prospective clinical study. Clin Oral Implants Res 2006;17(2):165-171.

14. Dueled E, Gotfredsen K, Trab Damsgaard M, Hede B. Professional and patient-based evaluation of oral rehabilitation in patients with tooth agenesis. Clin Oral Implants Res 2009;20:729-736. 
15. Étienne O. Les facettes en céramique. Courbevoie : Éditions CDP, 2013:1-142.

16. Kokich V, Kinzer G, Janakievski J. Congenitally missing maxillary lateral incisors: Restorative replacement. Am J Orthod Dentofacial Orthop 2011;139(4):435-445.

17. Kulkarni M, Agrawal T, Kheur S. Tooth agenesis: newer concept. J Clin Pediatr Dent 2011;36(1):65-69.

18. Lam WY, Botelho MG, Mc Grath CP. Longevity of implant crowns and 2-unit cantilevered resin-bonded bridges. Clin Oral Implant Res 2013; 24(12):1369-1374.

19. Lam WY, Mc Grath CP, Botelho MG. Impact of complications of single tooth restorations on oral health-related quality of life. Clin Oral Implant Res 2014;25(1):67-73.

20. Lehmann N, Simon AL, Tirlet G. Édentement unitaire : de l'observation clinique à la prise de décision thérapeutique. (1 ${ }^{\text {re }}$ partie). Rev Odont Stomat 2006;5:33-61.

21. Ludwig B, Zachrisson BU, Rosa M. Non-compliance space closure in patients with missing lateral incisors. J Clin Orthod 2013;47(3):180-187.

22. Magne $P$, Belser $U$. Restaurations adhésives en céramique : approche biomimétique. Quintessence, 2003.

23. Manhart J. Esthétique antérieure parfaite grâce aux facettes céramiques collées. Rev Mens Suisse Odontostomatol 2011:1:39-50.

24. Morgon L, Brossier $P$, Poulet $H$. Les agénésies dentaires dans notre pratique quotidienne. Inf Dent 2000;4(1):231-236.

25. Nordquist GG, Mc Neill RW. Orthodontic vs restorative treatment of the congenitally absent lateral incisor - periodontal and occlusal evaluation. J Periodontol 1975;46: 139-143.

26. Oesterle LJ, Cronin RJ Jr. Adult growth, aging, and the single-tooth implant. Int J Oral Maxillofac Implants 2000;15(2):252-260.

27. OlsenTM, Kokich VG. Postorthodontic root approximation after opening space for maxillary lateral incisor implants. Am J Orthod Dentofac Orthop. 2010;137(2): $158 \mathrm{e} 1-158 \mathrm{e} 8$.

28. Oshima $\mathrm{M}$, et al. Functional tooth regeneration using a bioengineered tooth unit as a mature organ replacement regenerative therapy. PLoS One 2011;6(7):e21531.

29. Robertsson S, Mohlin B. The congenitally missing upper lateral incisor. A retrospective study of orthodontic versus restorative treatment. Eur J Orthod 2000;22:697-710.

30. Rosa $\mathrm{M}$, Zachrisson BU. Integrating space closure and esthetic dentistry in patients with missing maxillary lateral incisors. J Clin Orthod 2007;41(9):563-573.

31. Rosa M, Zachrisson BU. The space closure alternative for missing maxillary lateral incisors: an update. J Clin Orthod 2010;44(9):540-549.

32. Song $S$, Zhao R, He H, Zhang J, Feng H, Lin L. WNT10A variants are associated with non-syndromic tooth agenesis in the general population. Hum Genet 2013 Sept 17. [Epub ahead of print]

33. Suarez BK, Spence MA. The genetics of tooth agenesis. J Dent Res 1974;53: 781-785.

34. Thilander B, Odman J, Lekholm U. Orthodontic aspects of the use of oral implants in adolescents: a 10-year follow-up study. Eur J Orthod 2001;23(6):715-31.

35. Thordarson A, Zachrisson BU, Mjör IA. Remodeling of canines to the shape of lateral incisors by grinding: a long term clinical and radiographic evaluation. Am J Orthod Dentofac Orthop 1991;100:123-132.

36. Tirlet G. Les bridges collés cantilever au service de l'édentement unitaire antérieur. Conf $16^{\text {es }}$ Journées Orthod, Paris, 2013.

37. Tirlet G, Attal JP. Le gradient thérapeutique : un concept médical pour les traitements esthétiques. Inf Dent 2009;91(41/42):2561-2568.

38. Tirlet G, Bazos P. Bioémulation et nouveau référentiel. Dentoscope 2014;123:10-20.

39. Tuverson DL. Orthodontic treatment using canines in place of missing maxillary lateral incisors. Am J Orthod 1970;58(2):109-127.

40. Van Dalen A, Feilzer AJ, Klevarlaan CJ. A literature review of two-unit cantilevered FPDs. Int J Prosthodont 2004;17(3):281-284. 
41. Vastardis $H$. The genetics of human tooth agenesis: New discoveries for understanding dental anomalies. Am J Orthod Dentofacial Orthop 2000;117(6):650-656.

42. Wong TL, Botelho MG. The fatigue bond strength of fixed-fixed versus cantilever resin-bonded partial fixed dental prostheses. J Prosthet Dent 2014;111(2):136-141.

43. Zachrisson BU. Improving the esthetic outcome of canine substitution for missing maxillary lateral incisors. World J Orthod 2007;8(1):72-79.

44. Zachrisson BU, Rosa M, Toreskog S. Congenitally missing maxillary lateral incisors: canine substitution. Am J Orthod Dentofacial Orthop 2011;139(4) :434-444. 